\title{
DRIMM: DRINK MIXING MACHINE UNTUK MEMBANTU PEDAGANG MINUMAN MENENTUKAN TAKARAN AIR YANG KONSISTEN
}

\author{
Muhammad Adam N.H ${ }^{1}$, Mohamad Nurkamal Fauzan ${ }^{2}$, Roni Habibi ${ }^{3}$, Noviana Riza ${ }^{4}$ \\ DIV Teknik Informatika \\ Politeknik Pos Indonesia \\ Bandung, Indonesia \\ addam.zoldyck@gmail.com ${ }^{1}$, m.nurkamal.f@poltekpos.ac.id ${ }^{2}$, ronihabibi@ poltekpos.ac.id $^{3}$, \\ $\underline{\text { novianariza@poltekpos.ac.id }}^{4}$
}

\begin{abstract}
Abstrak
Elektrolit merupakan salah satu dari cairan yang ada pada tubuh manusia. Elektrolit ini digunakan untuk menjaga keseimbangan cairan yang ada pada tubuh. Kekurangan elektrolit dapat mengakibatkan dehidrasi. Dehidrasi dapat diatasi dengan minum minuman yang mengandung elektrolit. Namun, minuman yang dijual oleh pedagang itu belum tentu mengandung elektrolit yang aman dikonsumsi oleh tubuh manusia, sehingga diperlukan alat untuk membantu pedagang untuk membuat minuman dengan kandungan elektrolit yang aman bagi tubuh manusia. Dari masalah tersebut, penulis membuat sebuah alat untuk mencampur minuman. Alat ini diberi nama DRIMM (Drink Mixing Machine). DRIMM akan memberi takaran campuran air minuman dengan takaran yang sudah diolah dengan menggunakan metode Regresi Linier Berganda. Dari hasil percobaan yang dilakukan, alat dapat membuat campuran air dengan konsentrasi elektrolit rata-rata sebesar 654 PPM. Sehingga kandungan elektrolit yang ada pada minuman tersebut sesuai dengan dosis yang aman dikonsumsi oleh tubuh. Alat ini, diharapkan dapat membantu pedagang dalam proses pembuatan minumannya. Serta membuat pedagang tidak perlu khawatir dengan kandungan elektrolit didalam minumannya.
\end{abstract}

Kata Kunci: Elektrolit, Arduino, Mikrokontroller, Mixing, Regresi Linier Berganda

\section{Abstract}

Electrolyte is one of the fluids in the human body. This electrolyte is used to maintain fluid balance in the body. Lack of electrolytes can lead to dehydration. Dehydration can be overcome by drinking drinks that contain electrolytes. However, the drinks sold by traders do not necessarily contain electrolytes that are safe for consumption by the human body. So a machine to help traders to make drinks with safe electrolyte content is necessary. From these problems, the authors has made a machine for mixing drinks. This tool is named DRIMM (Drink Mixing Machine). DRIMM will provide a mixture of drinking water with a dose that has been processed using the Multiple Linear Regression method. From the results of experiments conducted, the tool can make a mixture of water with an average electrolyte concentration of 654 PPM. So that the electrolyte content in the drink is in accordance with a safe dose for consumption by the body. With this tool, it is expected to help traders in the process of making their drinks. The trader as well as the customers will no longer worry about the electrolyte content in their drinks.

Keywords: Electrolytes, Arduino, Microcontroller, Mixing, Multiple Linear Regression

\section{Pendahuluan}

\subsection{Latar Belakang}

ELektrolit merupakan salah satu dari cairan yang ada didalam tubuh manusia [1]. Elektrolit ini digunakan untuk menjaga keseimbangan cairan yang ada didalam tubuh manusia [2]. Kekurangan elektrolit dalam tubuh manusia, menyebabkan orang tersebut merasa dehidrasi [3]. Dehidrasi dapat diatasi dengan meminum minuman yang mengandung elektrolit yang cukup untuk tubuh [4]. Terdapat empat komponen

Muhammad Adam N.H, Mohamad Nurkamal Fauzan, Roni Habibi, Noviana Riza 
mayor elektrolit yang ada dalam tuhub manusia. Natrium (NA+), Kalium (K+), Klorida (CL-), dan Bikarbobat (HCO3). Cairan ini digunakan untuk menjaga tekanan osmosis dalam tubuh manusia [2]. Normalnya, kadar natrium dalam darah terdapat pada angka 135 - 145 milimol/liter. Untuk kadar kalium sebesar 3,5 - 5 milimol/liter. Klorida yang normal sebesar 98 - 108 milimol/liter. Dan untuk bikarbonat kadar normalnya sebanyak 22 - 30 milimol/liter [5]. Minuman tersebut dapat dibeli secara langsung kepada pedagang yang menjual minuman tersebut. Namun orang tidak mengetahui kandungan elektrolit didalam minuman yang dijual pedagang tersebut aman untuk dikonsumsi atau tidak.

Pada era perkembangan zaman yang modern ini, terdapat banyak teknologi yang dapat dimanfaatkan. Salah satu teknologi yang terkenal yaitu mikrokontroler Arduino. Mikrokontroler Arduino merupakan sebuah platform elektronik yang bersifat open-source [6]. Pemakaian arduino tergolong mudah dan fleksibel, cocok digunakan oleh orang yang mencoba membuat sebuah prototipe. Arduino mempunyai 16 buah Pin PWM, 16 buah Pin Input Analog. Sumber listrik arduino dapat berupa sambungan dari USB kabel, dan dapat pula menggunakan baterai [7]. Mikrokontroler ini sudah banyak diterapkan dalam kehidupan masyarakat. Penerapannya juga sudah banyak di berbagai bidang. Misalnya dalam bidang keamanan terdapat pintu otomatis berbasis mikrokontroler Arduino. Dalam penerapannya, arduino dihubungkan dengan sebuah selenoid lock untuk kunci pintunya. Untuk membuka kunci atau menutup kuncinya, menggunakan kontrol dari Android [8]. Ada pula yang menggunakan RFID sebagai kunci untuk membuka pintunya [9].

Didalam kehidupan sehari-hari pun terdapat pengaplikasian arduino. Contohnya yaitu adanya aplikasi smart home. Arduino digunakan untuk mengontrol peralatan elektronik yang terinstall pada bagian rumah. Mulai dari lampu, alarm kebakaran, kipas angin, bahkan untuk menyiram pot tanaman [10]. Didasari oleh latar belakang tersebut. Penulis berinisiatif membuat sebuah inovasi untuk merakit sebuah mesin pencampur air mineral dengan air berasa lainnya. Alat ini nantinya diperuntukkan oleh pedagang minuman yang menjual minuman berupa campuran air meneral dengan air berasa lainnya. Alat ini diberi nama DRIMM. DRIMM merupakan singkatan dari Drink Mixing Machine. Alat ini berguna untuk memberi komposisi takaran minuman yang konsisten. Konsisten berarti kandungan elektrolit yang ada didalam minuman tersebut tidak akan berbeda antara gelas pertama dan gelas kedua dan seterusnya. Alat ini akan mencampurkan air dengan air berasa yang memiliki jumlah kandungan elektrolit yang aman dikonsumsi oleh tubuh. Berdasarkan hasil dari penelitian yang dilakukan, alat ini menghasilkan campuran air mineral dan air perasan jeruk dengan kandungan elektrolit sebesar 654 PPM. Komponen alat ini antara lain terdapat pompa peristaltik untuk mendorong air berasa ke dalam gelas. Adapula pompa mini digunakan untuk memompa air mineral ke dalam gelas. Metode Regresi Linier Berganda diterapkan untuk mengetahui hubungan variabel air mineral (X1) dan air berasa (X2) dengan variabel kandungan elektrolit (Y). Dengan adanya alat ini, diharapkan pedagang dapat menghemat tenaga dalam proses pembuatan minumannya, serta tidak perlu khawatir dengan kandungan elektrolit yang ada didalam minuman tersebut.

\subsection{Identifikasi Masalah}

Berdasarkan masalah yang sedang dihadapi, maka dapat dijabarkan permasalahan sebagai berikut: 1. Belum adanya alat untuk membuat campuran minuman yang mengandung eleltrolit dengan takaran yang konsisten.

2. Bagaimana membuat sebuah alat untuk memudahkan pedagang minuman membuat campuran minuman.

3. Bagaimana merakit sebuah alat untuk membuat campuran minuman dengan takaran elektrolit yang konsisten.

4. Menentukan takaran elektrolit menggunakan Metode Regresi Linier Berganda pada alat.

5. Bagaimana mengetahui pengaruh variabel X1 dan variabel X2 terhadap variable terikat Y menggunakan Metode Regresi Linier Berganda.

\subsection{Tujuan dan Manfaat}

Berdasarkan identifikasi masalah, tujuan dari penelitian ini yaitu:

1. Membuat sebuah alat untuk membantu pedagang minuman membuat campuran minuman berelektrolit.

Muhammad Adam N.H, Mohamad Nurkamal Fauzan, Roni Habibi, Noviana Riza 
2. Merakit sebuah alat untuk membuat campuran minuman dengan takaran elektrolit yang konsisten.

3. Mengetahui pengaruh variabel $\mathrm{X} 1$ dan variabel $\mathrm{X} 2$ terhadap variabel terikat $\mathrm{Y}$ menggunakan Metode Regresi Linier Berganda.

4. Menghasilkan sebuah rumus Regresi Linier Berganda.

5. Menciptakan sebuah alat untuk membantu pedagang minuman membuat campuran minuman berelektrolit.

6. Membuat alat untuk membuat campuran minuman dengan komposisi takaran elektrolit yang konsisten.

7. Mempercepat pedagang dalam melakukan proses pembuatan minuman yang dijualnya.

\section{LANDASAN TEORI}

\subsection{Teori Umum}

\subsubsection{Prototyping}

Prototipe didefinisikan suatu versi dari sebuah potensial yang memberikan ide bagi para pengembang dan calon pengguna, bagaimana sistem akan berfungsi dalam bentuk yang telah selesai. Proses pembuatan prototipe ini disebut prototyping. Dasar dari pemikiran ini adalah membuat prototipe secepat mungkin, bahkan dalam waktu semalam, lalu memperoleh umpan balik dari pengguna yang akan memungkinkan prototipe tersebut diperbaiki kembali dengan sangat cepat [11].

\subsubsection{Regresi Linier Berganda}

Terdapat dua macam regresi linier. Regresi yang pertama yaitu Regresi Linier Sederhana, regresi ini hanya melibatkan satu variabel pengaruh. Kedua yaitu Regresi Linier Berganda, regresi ini melibatkan dua atau lebih variabel pemberi pengaruh [12].

$$
\mathrm{Y}=\mathrm{a}+\mathrm{b}_{1} \mathrm{X}_{1}+\mathrm{b}_{2} \mathrm{X}_{2}+\ldots+\mathrm{b}_{\mathrm{n}} \mathrm{X}_{\mathrm{n}}
$$

\section{Gambar II.1: Rumus Regresi Linier Berganda}

Gambar II.1 merupakan rumus Regresi Linier Berganda. Y merupakan variable dependen atau terikat. Simbol a merupakan sebuah konstanta. Simbol b merupakan nilai dari koefisien regresi. Dan
Simbol X merupakan variabel bebas atau independen [13].

\subsection{Perangkat Yang Digunakan}

\subsubsection{Arduino}

Arduino Uno merupakan pengendali micro single-board yang bersifat open-source, diturunkan dari Wiring platform, dirancang untuk memudahkan pengguna elektronik dalam berbagai bidang. Perangkat kerasnya memiliki prosesor Atmel AVR dan perangkat lunaknya memiliki bahasa pemrograman sendiri. Arduino adalah kit mikrokontroler yang serba bisa dan sangat mudah penggunaanya. Untuk membuatnya diperlukan chip programmer (untuk menanamkan bootloader Arduino pada chip). Arduino Uno didasarkan pada Atmega328 (datasheet). Arduino Uno mempunya 14 pin digital input/output (6 diantaranya dapat digunakan untuk output PWM), 6 input analog sebuah isolator Kristal $16 \mathrm{MHz}$, sebuah koneksi USB, sebuah power jack, sebuah ICSP header, dan mikrokontroler, mudah menghubungkannya ke sebuah computer dengan sebuah kabel USB atau mensuplaynya dengan sebuah adaptor AC ke DC atau menggunakan baterai untuk memulainya [14].

\subsubsection{Pompa Peristaltik}

Pompa Peristaltik yaitu pompa yang digunakan untuk memindahkan suatu fluida atau cairan dari tempat satu ke tempat yang lain [15]. Proses pemompaan pompa peristaltik berbeda dengan pompa-pompa lainnya.

Pompa peristaltik tidak bersentuhan langsung dengan cairan yang dipompanya. Carian tersebut masuk kedalam pipa kemudian ditekan oleh roller. Tekanan tersebut membuat cairan tersebut dapat bergerak sesuai arah putar dari roller [16].

\subsubsection{Diaphragm Pump}

Diaphragm Pump digunakan untuk mengalirkan cairan ke dalam gelas. Berbeda dengan Pompa Peristaltik, Diaphragm Pump tidak perlu melakukan pancingan untuk hisapan awal pemakaian. Diaphragm Pump aman digunakan untuk pemakaian pada air [17].

\section{GAMBARAN OBYEK STUDI}

\subsection{DRIMM: Drink Mixing Machine}

DRIMM merupakan sebuah singkatan dari Drink Mixing Machine. Fungsi dari alat ini yaitu digunakan

Muhammad Adam N.H, Mohamad Nurkamal Fauzan, Roni Habibi, Noviana Riza 
untuk mencampurkan air mineral dan air berasa dengan takaran elektrolit dalam minuman sesuai dengan dosis yang aman untuk tubuh. DRIMM dibuat menggunakan mikrokontroler arduino. Alat ini memiliki dua jenis pompa. Pompa pertama yaitu pompa peristaltik yang digunakan untuk memompa air berasa ke dalam gelas. Pompa kedua yaitu pompa mini, digunakan untuk mendorong air mineral ke dalam gelas. Metode Regresi Linier Berganda diterapkan untuk mendapatkan jumlah kandungan elektrolit yang aman dikonsumsi oleh tubuh.

\section{METODOLOGI PENELITIAN}

\subsection{Diagram Alur Metodologi Penelitian}

Metodologi penelitian merupakan formula dalam penerapan penelitian, yang pada saat melakukan penelitian terdapat langkah-langkah dan hasil penelitian [19]. Metodologi penelitian ini terdiri dari beberapa tahapan yang digunakan sebagai acuan untuk melaksanakan penelitian.

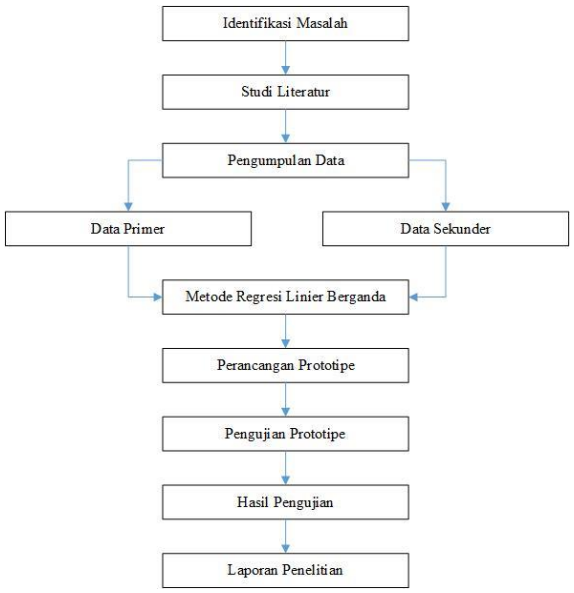

Gambar IV.1: Diagram Alur Metodologi Penelitian

\subsection{Tahapan Diagram Alur Metodologi Penelitian}

Penjabaran tahapan penelitian dalam gambar IV.1 diagram alur metodologi penelitian dijelaskan sebagai berikut:

\subsubsection{Identifikasi Masalah}

Tahapan ini merupakan tahap mengumpulkan masalah yang mendasari dilakukannya sebuah penelitian, mengumpulkan bukti-bukti yang menjadi latar belakang masalah sehingga penelitian tersebut sangat perlu untuk dilaksanakan. Memotivasi peneliti dan audien untuk mencari solusi dan menerima hasil dan membantu memahami alasan yang terkait dengan penelitian masalah [19].

\subsubsection{Studi Literatur}

Tahapan ini merupakan tahap mencari referensireferensi yang digunakan sebagai bahan rujukan penelitian. Referensi yang dipakai berupa jurnal nasional maupun internasional dan buku. Topik yang terdapat pada jurnal dan buku harus sesuai dengan topik dari penelitian yang dilakukan.

\subsubsection{Pengumpulan Data}

Tahapan ini merupakan tahap untuk mengumpulkan data-data yang akan dipakai pada penelitian. Terdapat dua jenis data yang dipakai. Data primer dan data sekunder. Data primer merupakan data yang secara langsung didapatkan oleh peneliti melalui cara-cara tertentu. Data sekunder merupakan data yang didapatkan melalui data yang sudah ada. Data primer yang digunakan dalam penelitian ini berupa data hasil eksperimen sampel minuman yang sudah dibeli. Sedangkan data sekunder menggunakan data yang sudah ada dari Kementerian Republik Indonesia.

\subsubsection{Metode Regresi Linier Berganda}

Tahapan ini merupakan tahap untuk melakukan perhitungan data yang telah diperoleh menggunakan metode Regresi Linier Berganda. Regresi Linier Berganda merupakan regresi yang memiliki dua atau lebih variabel pengaruh [12]. Regresi Linier Berganda digunakan untuk mengetahui ada atau tidak hubungan antara variabel bebas (x1) dan variabel bebas lainnya (x2) terhadap variabel terikat (y) [13]. Dalam penelitian ini, variabel bebas (x1) merupakan air mineral. Variabel bebas lainnya (x2) merupakan air berasa. Dan variabel terikatnya (y) yaitu jumlah kandungan elektrolit. Metode Regresi Linier Berganda juga digunakan untuk meramalkan apabila terdapat perubahan dari variabel $\mathrm{x} 1$ dan $\mathrm{x} 2$.

\subsubsection{Perancangan Prototipe}

Tahapan ini merupakan tahap prototipe dirancang menggunakan UML (Unified Modeling Language).

\subsubsection{Use Case Diagram}

Use case diagram menunjukkan hubungan antara Aktor dengan Relasinya. Berikut use case diagram yang menggambarkan secara umum alat yang dibuat.

Muhammad Adam N.H, Mohamad Nurkamal Fauzan, Roni Habibi, Noviana Riza 


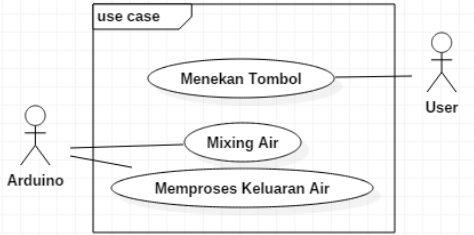

Gambar IV.2: Use Case Diagram Alat

\subsubsection{Scenario Use Case}

Setiap use case diagram, diberikan sebuah skenario untuk menjelaskan detail interaksi yang ada didalamnya. Berikut beberapa skenario yang ada dalam use case diagram.

\begin{tabular}{|c|c|}
\hline \multicolumn{2}{|l|}{ Indentifikasi } \\
\hline Nama & User Menekan Tombol \\
\hline Tujuan & $\begin{array}{l}\text { Untuk memerintahkan alat memompa } \\
\text { air ke dalam gelas. }\end{array}$ \\
\hline Aktor & User \\
\hline Kondisi Awal & Alat dalam keadaan standby \\
\hline Aksi Aktor & Reaksi Alat \\
\hline $\begin{array}{l}\text { User menekan tombol memberi } \\
\text { perintah kepada Arduino untuk } \\
\text { memompa air ke dalam gelas. }\end{array}$ & $\begin{array}{l}\text { Menerima sinval perintah dan } \\
\text { kemudian mulai melakukan eksekusi } \\
\text { perintah. }\end{array}$ \\
\hline Kondisi Akhir & $\begin{array}{l}\text { Alat mulai memompa air ke dalam } \\
\text { gelas. }\end{array}$ \\
\hline
\end{tabular}

Gambar IV.3: Scenario Use Case User Menekan Tombol

\begin{tabular}{|l|l|}
\hline Indentifikasi & Arduino Memproses Keluaran Air \\
\hline Nama & $\begin{array}{l}\text { Arduino dapat memproses kapasitas air } \\
\text { yang dikeluarkan. }\end{array}$ \\
\hline Tujuan & Arduino \\
\hline Aktor & User menekan tombol \\
\hline Kondisi Awal & Reaksi Alat \\
\hline Aksi Aktor & $\begin{array}{l}\text { Alat mulai memompa air ke dalam } \\
\text { gelas. }\end{array}$ \\
\hline $\begin{array}{l}\text { Arduino mulai melakukan prom } \\
\text { kapasitas air yang keluar. }\end{array}$ & Alat memompa air ke dalam gelas. \\
\hline Kondisi Akhir &
\end{tabular}

\section{Gambar IV.4: Scenario Use Case Mixing Air}

\begin{tabular}{|c|c|}
\hline \multicolumn{2}{|l|}{ Indentifikasi } \\
\hline Nama & Mixing Air \\
\hline Tujuan & $\begin{array}{l}\text { Mencampurkan air mineral dengan air } \\
\text { berasa. }\end{array}$ \\
\hline Aktor & Hardware \\
\hline \multicolumn{2}{|l|}{ Kondisi Awal } \\
\hline Aksi Aktor & Reaksi Alat \\
\hline $\begin{array}{l}\text { Arduino mengirimkan perintah } \\
\text { memasukkan air kedalam gelas. }\end{array}$ & $\begin{array}{l}\text { Alat mulai memompa air mineral dan } \\
\text { air berasa ke dalam gelas. }\end{array}$ \\
\hline Kondisi Akhir & Air tercampur didalam gelas. \\
\hline
\end{tabular}

Gambar IV.5: Scenario Use Case Memproses Keluaran Air

\subsubsection{Class Diagram}

Class diagram digunakan untuk menghubungkan class-class yang ada pada sistem alat. Class diagram menggambarkan struktur statik dari sebuah sistem alat.

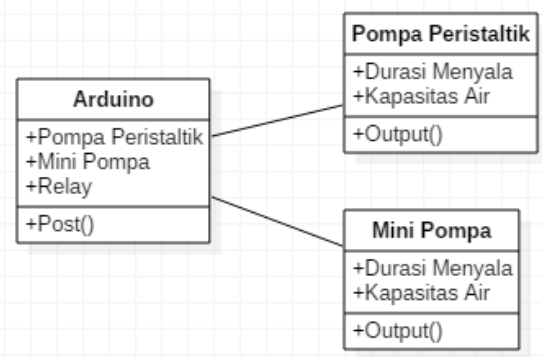

Gambar IV.6: Class Diagram

\subsubsection{Activity Diagram}

Activity diagram memodelkan aliran kerja atau workflow dari urutan aktivitas pada use case diagram yang telah dibuat.

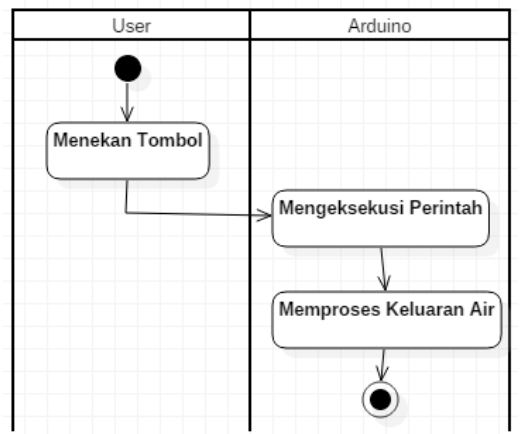

Gambar IV.7: Activity Diagram User Menekan Tombol

Muhammad Adam N.H, Mohamad Nurkamal Fauzan, Roni Habibi, Noviana Riza Jurnal Ilmiah Teknologi Informasi Terapan

Volume 5, No 2, 15 April 2019 


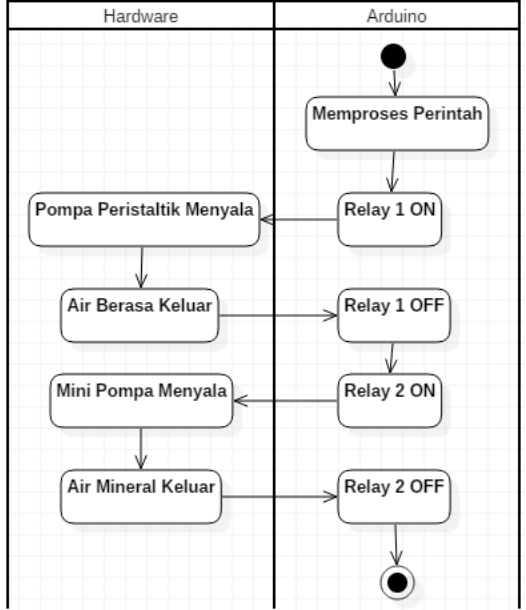

Gambar IV.8: Activity Diagram Mixing Air

\subsubsection{Arsitektur Prototipe}

Arsitektur prototipe menjelaskan tentang hubungan antara tiap-tiap komponen yang dipakai dalam rangkaian alat prototipe. Arsitektur prototype dijelaskan pada gambar IV.9. Digambarkan dari awal user menekan tombol sampai pada hasil akhir berupa campuran air mineral dengan air perasan jeruk.

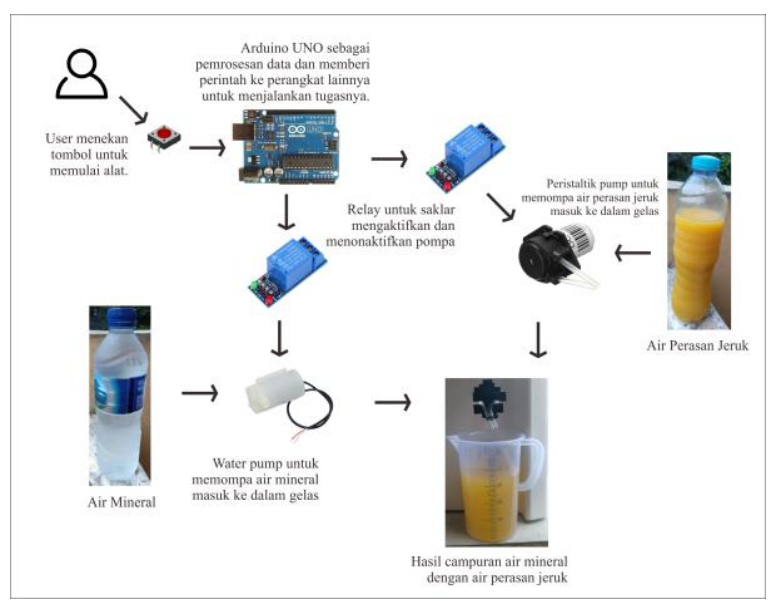

Gambar IV.9: Arsitektur Prototipe DRIMM

\subsubsection{Skematik Pengkabelan Prototipe}

Skematik pengkabelan prototipe dirancang menggunakan software Fritzing. Setiap pin dihubungkan sesuai dengan tempatnya masingmasing. Pada gambar V.1, relay digunakan untuk menghubungkan kabel Positif (+) dari baterai ke pompa. Karena pompa yang digunakan bekerja pada voltase $6-12 \mathrm{~V}$, maka baterai $9 \mathrm{~V}$ digunakan. Tutorial perakitan komponen:
1. Siapkan alat dan bahan (Arduino UNO, 2 buah relay, pompa peristaltik, pompa air, 2 buah baterai, 1 buah tombol, dan sejumlah kabel jumper).

2. Hubungkan tombol dengan arduino pada pin 1 arduino. Tombol juga dihubungkan dengan pin GND dan VCC 5V.

3. Hubungkan pin VCC relay $1 \mathrm{ke} \mathrm{VCC} 5 \mathrm{~V}$ yang ada pada arduino.

4. Hubungkan pin GDN relay 1 ke GDN pada arduino.

5. Hubungkan pin IN relay 1 ke pin nomor 4 pada arduino.

6. Hubungkan baterai dengan relay 1 pada pin NC.

7. Hubungkan pompa peristaltik dengan pin NO pada relay 1 .

8. Lakukan langkah yang sama untuk relay 2 .

9. Hubungkan pin VCC relay 2 ke VCC $5 \mathrm{~V}$ arduino.

10. Hubungkan pin GDN relay 2 ke GDN pada arduino.

11. Hubungkan pin IN relay 2 ke pin nomor 7 pada arduino.

12. Hubungkan baterai dengan relay 2 pada pin NC.

13. Hubungkan pompa peristaltik dengan pin $\mathrm{NO}$ pada relay 2 .

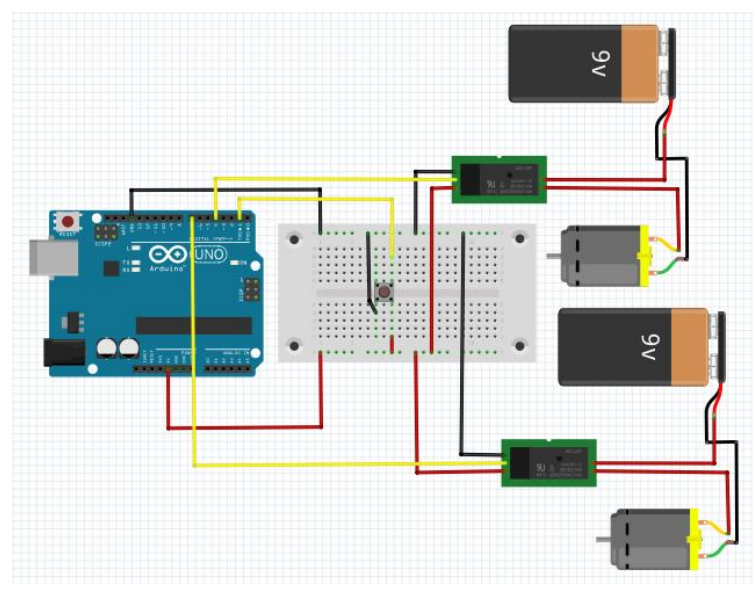

Gambar IV.10: Skematik Pengkabelan Prototype

\subsubsection{Pengujian Prototipe}

Tahapan ini merupakan tahap untuk melakukan uji coba terhadap prototipe yang telah dirancang. Tahap ini bertujuan supaya rancangan alat yang telah

Muhammad Adam N.H, Mohamad Nurkamal Fauzan, Roni Habibi, Noviana Riza Jurnal Ilmiah Teknologi Informasi Terapan

Volume 5, No 2, 15 April 2019 
dibuat sesuai dengan perancangan awal. Tahap ini berupa eksperimen trial and error untuk mendapatkan nilai yang diinginkan.

\subsubsection{Hasil Pengujian}

Tahapan ini merupakan tahap untuk melakukan pembahasan terhadap pengujian yang telah dilakukan. Tahap ini menentukan apakah prototipe yang telah dibuat mampu menyelesaikan masalah yang telah ditentukan atau belum mampu untuk menyelesaikannya. Setelah dilaksanakan tahap ini, peneliti dapat memutuskan apakah akan melanjutkan penelitian atau kembali ke langkah ketiga untuk memperbaiki dan atau meningkatkan efektifitas dari penelitian.

\subsubsection{Laporan Penelitian}

Tahapan terakhir yaitu mengkomunikasikan hasil dari penelitian yang telah dilakukan. Komunikasi ini dapat berupa dalam beberapa bentuk, contohnya lewat laporan atau bentuk lisan berupa presentasi. Diharapkan hasil dari penelitian ini dapat mengatasi permasalah yang ada.

\section{PENGUJIAN DAN HASIL}

\subsection{Pengujian}

\subsubsection{Pengujian Metode}

Metode Regresi Linier Berganda pada penelitian ini digunakan untuk:

1. Membuat persamaan matematika regresi berganda yang nantinya dapat diterapkan pada alat.

2. Menguji hubungan antara variabel $\mathrm{X} 1$ dengan variabel dependen $\mathrm{Y}$.

3. Menguji hubungan antara variabel X2 dengan variabel dependen $\mathrm{Y}$.

4. Menguji seluruh variabel independen terhadap variabel dependen.

5. Mengukur besarnya konstribusi seluruh variabel independen terhadap variable dependen.

Pengujian metode Regresi Linier Berganda menggunakan bantuan aplikasi MS Excel. Data eksperimen yang telah diperoleh, tabel V.1, dimasukkan ke dalam Excel. Dengan menggunakan menu Data Analysis, memunculkan pilihan regresi. Memasukkan nilai dependennya, dan indendennya, MS Excel memproses hasil dari regresi data tersebut.

Tabel V.1: Tabel Data Eksperimen

\begin{tabular}{llll}
\hline \hline No & $\mathbf{X 1}(\mathbf{m l})$ & $\mathbf{X 2}(\mathbf{m l})$ & $\mathbf{Y}(\mathbf{p p m})$ \\
\hline \hline 1 & 300 & 75 & 645 \\
2 & 400 & 100 & 699 \\
3 & 250 & 190 & 1040 \\
4 & 450 & 190 & 847 \\
5 & 200 & 50 & 654 \\
6 & 250 & 100 & 801 \\
7 & 350 & 190 & 961 \\
\hline \hline
\end{tabular}

\subsubsection{Pengujian Alat}

Pada proses pengujian alat, terlebih dahulu komponen-komponen dari prototype dirakit terlebih dahulu. Setiap kabel dihubungkan dengan pin-pin yang terdapat pada arduino sesuai dengan perancangan yang telah ditentukan. Setelah proses perakitan, arduino diberi skript program melalui software Arduino IDE. Alat kemudian masuk kedalam proses pengujian. Pengujian alat ini dilakukan dengan melakukan uji coba menggunakan air mineral dan air perasan jeruk. Pengujian ini dilakukan dengan beberapa kali percobaan, guna untuk mendapatkan kadar elektrolit yang sesuai. Percobaan dilakukan dengan mengganti-ganti angka delay pada skript software Arduino IDE. Setiap percobaan yang dilakukan, hasil campuran air mineral dengan air perasan jeruk diuji dengan TDS Meter. Cara kerja dari alat ini yaitu; Ketika tombol ditekan oleh user, rotor menyala dan membuat kipas pada rotor berputar. Perputaran kipas inilah yang membuat air mengalir kedalam pipa. Begitu pula dengan pompa peristaltik, pompa peristaltic menyedot air perasan jeruk dari wadah kemudian meyalurkannya kedalam gelas.

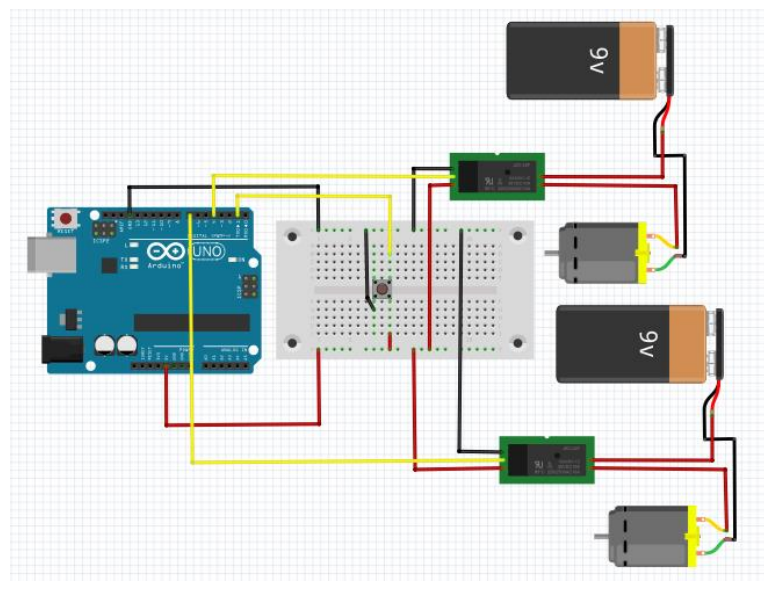

Gambar V.1: Skematik Kabel Prototype

\subsection{Hasil}

\subsubsection{Hasil Pengujian Metode}

Muhammad Adam N.H, Mohamad Nurkamal Fauzan, Roni Habibi, Noviana Riza 


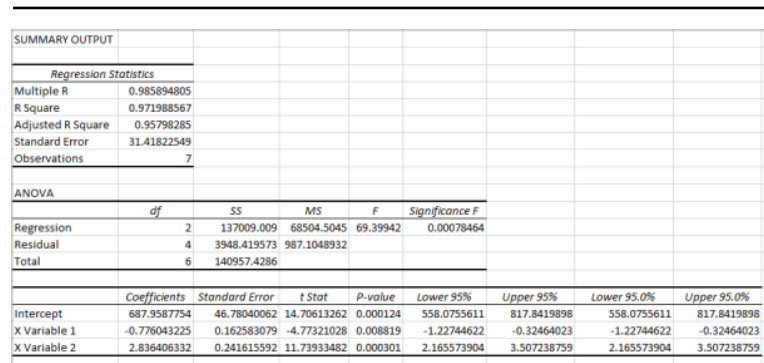

Gambar V.2: Hasil Pengujian Data Eksperimen

Hasil pengujian metode regresi linier berganda menggunakan MS Excel, dapat dilihat pada gambar V.2.

\subsubsection{Membuat Persamaan Regresi}

\begin{tabular}{|l|r|r|c|c|}
\hline & \multicolumn{1}{c}{ Coefficients } & Standard Error & \multicolumn{1}{c}{ t Stat } & $P$-value \\
\hline Intercept & 687.9587754 & 46.78040062 & 14.70613262 & 0.000124 \\
\hline X Variable 1 & -0.776043225 & 0.162583079 & -4.77321028 & 0.008819 \\
\hline X Variable 2 & 2.836406332 & 0.241615592 & 11.73933482 & 0.000301 \\
\hline
\end{tabular}

Gambar V.3: Tabel Coefficients

Setelah mendapatkan hasil regresi pada MS Excel, untuk membuat persamaan regresi, harus melihat gambar tabel coefficients. Dalam tabel tersebut kolom Coefficients yang digunakan untuk membuat persamaan regresi.

$$
\mathrm{Y}=\mathrm{a}+\mathrm{b}_{1} \mathrm{X}_{1}+\mathrm{b}_{2} \mathrm{X}_{2}+\ldots+\mathrm{b}_{\mathrm{n}} \mathrm{X}_{\mathrm{n}}
$$

\section{Gambar V.4: Rumus Regresi Linier Berganda}

Dengan memasukkan angka yang ada pada kolom Coefficients kedalam rumus regresi linier, gambar V.4. Diperoleh konstanta (a) adalah 687,96. koefisien b1 adalah -0,78. Koefisien b2 adalah 2,84. Sehingga rumus regresi yang didapat menjadi seperti pada gambar VI.1

$$
\mathrm{Y}=687,96-0,78 \mathrm{X}_{1}+2,84 \mathrm{X}_{2}
$$

\section{Gambar V.5: Persamaan Baru Regresi Linier Berganda}

\subsubsection{Hubungan Variabel $X 1$ dan $Y$}

Melihat pada gambar V.3, untuk mengetahui ada tidaknya hubungan antara variabel $\mathrm{X} 1$ dan $\mathrm{Y}$ perlu memperhatikan kolom paling kanan yaitu $\mathrm{P}$-value. Jika nilai dari $\mathrm{P}$-value lebih kecil dari nilai 0,05 maka terdapat pengaruh antara variabel X1 dan Y. Pada tabel, nilai P-value dari variabel X1 adalah 0,008819 yang nilainya lebih kecil daripada 0,05. Hal ini membuktikan bahwa terdapat pengaruh antara variable X1 dan Y.

\subsubsection{Hubungan Variabel X2 dan Y}

Sama halnya dengan mencari hubungan variabel $\mathrm{X} 1$ dan $\mathrm{Y}$, variabel $\mathrm{X} 2$ pun dilakukan dengan cara yang sama. Apabila nilai dari P-value lebih kecil dari 0,05 , maka terdapat pengaruh antara variabel X2 dan Y. Pada tabel, nilai P-value dari variable X2 adalah 0,000301 yang nilainya lebih kecil daripada 0,05 . Hal ini membuktikan bahwa terdapat pengaruh antara variabel X2 dan Y.

\subsubsection{Hubungan Bersama Variabel X1 dan X2

\begin{tabular}{|c|c|c|c|c|c|c|}
\hline ANOVA & & & & & & \\
\hline & $d f$ & & SS & MS & $F$ & Significance $F$ \\
\hline Regression & & 2 & 137009.009 & 68504.5045 & 69.39942 & 0.00078464 \\
\hline Residual & & 4 & 3948.419573 & 987.1048932 & & \\
\hline Total & & 6 & 140957.4286 & & & \\
\hline
\end{tabular} Terhadap Y}

Gambar V.6: Tabel ANNOVA

Untuk mengetahui hubungan bersama variabel X1 dan X2 terhadap Y, harus memperhatikan gambar tabel V.6. Hampir sama caranya dengan mencari hubungan antar variabel, untuk mencari hubungan bersama ini melihat kolom Significance $F$. Jika nilai dari kolom Significance $F$ kurang dari 0,05, maka terdapat pengaruh bersama variabel X1 dan X2 terhadap Y. Nilai Significance $F$ pada tabel adalah 0,00078464 , yang nilainya lebih kecil dari 0,05 . Berarti terdapat hubungan bersama antara variabel X1 dan X2 terhadap Y.

\subsubsection{Konstribusi Variabel Independen Terhadap Variabel Dependen}

\begin{tabular}{|l|r|}
\hline \multicolumn{2}{|l|}{ SUMMARY OUTPUT } \\
\hline \multicolumn{2}{|c|}{ Regression Statistics } \\
\hline Multiple R & 0.985894805 \\
\hline R Square & 0.971988567 \\
\hline Adjusted R Square & 0.95798285 \\
\hline Standard Error & 31.41822549 \\
\hline Observations & 7 \\
\hline
\end{tabular}

Gambar V.7: Tabel Summary Output

Besarnya konstribusi variabel independen terhadap variabel dependen biasanya dinyatakan dalam pernsentase. Nilai besarnya konstribusi dapat dilihat pada table Summary Output. Pada gambar V.7,

Muhammad Adam N.H, Mohamad Nurkamal Fauzan, Roni Habibi, Noviana Riza 
konstribusi variabel dinyatakan dengan besarnya $R$ Square yang dijadikan persentasi. Dalam hal ini berarti konstribusi variable independen terhadap variabel dependen sebesar 97,2 persen.

\subsubsection{Hasil Pengujian Alat}
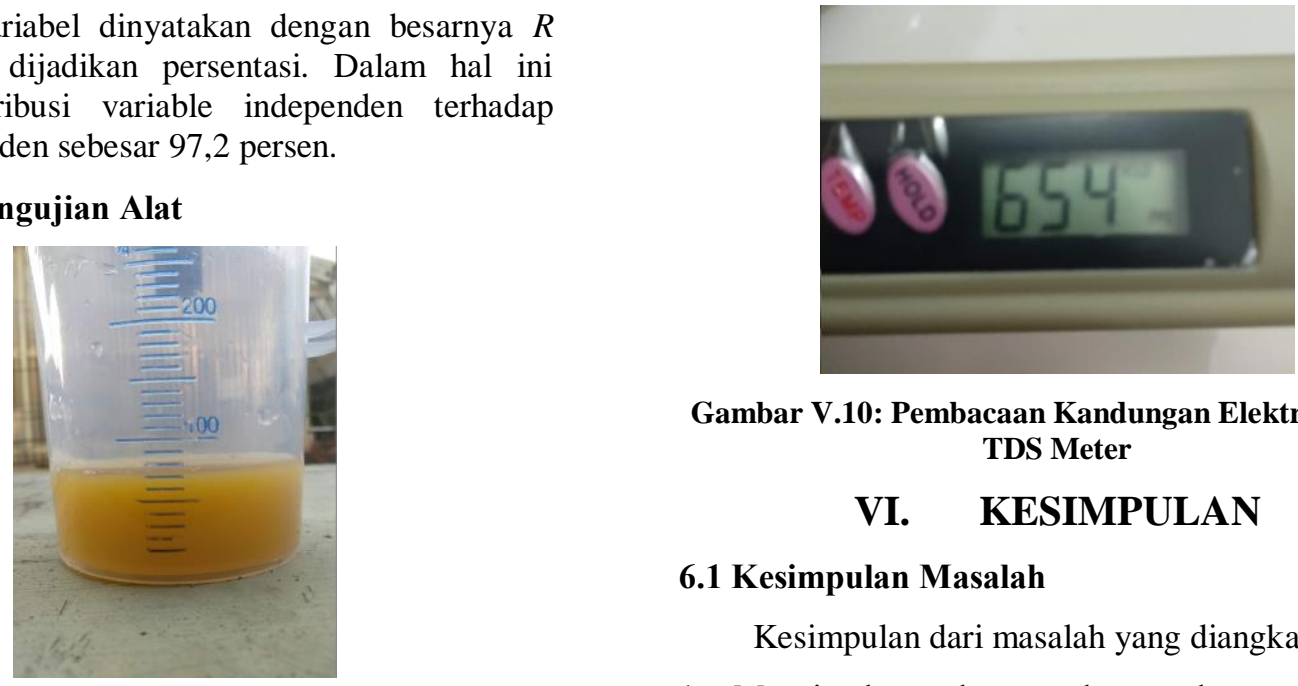

Gambar V.10: Pembacaan Kandungan Elektrolit Pada TDS Meter

\section{KESIMPULAN}

\subsection{Kesimpulan Masalah}

Kesimpulan dari masalah yang diangkat yaitu:

Gambar V.8: Hasil Keluaran Pompa Peristaltik

Hasil dari pengujian alat dari pengujian yang dilakukan, alat dapat bekerja dengan baik. Gambar V.8 menunjukkan bahwa pompa peristaltik dapat memompa air perasan jeruk sebanyak $70 \mathrm{ml}$. Kemudian ditambah dengan pompa air yang dapat memompa air mineral sebanyak $300 \mathrm{ml}$ dalam waktu 10 detik.

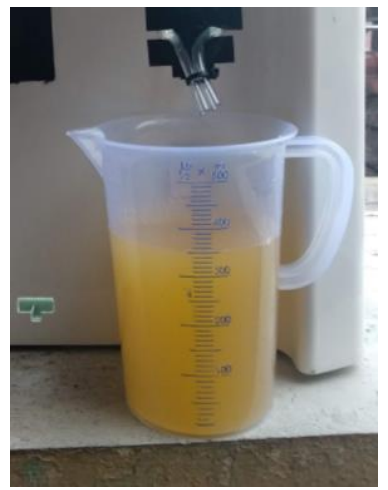

Gambar V.9: Hasil Akhir Minuman

Setelah alat selesai bekerja, minuman yang sudah dibuat kemudian dites menggunakan TDS Meter. Hasil TDS Meter menunjukkan angka 654 PPM. Sehingga setiap kali alat tersebut membuat minuman, kandungan elektrolit yang terdapat pada minuman tersebut sebesar 654 PPM.
1. Menciptakan alat untuk membantu pedagang minuman membuat campuran minuman berelektrolit.

2. Alat dapat membuat minuman dengan takaran elektrolit yang konsisten atau tidak berubah-ubah dengan kandungan elektrolit pada angka 654 PPM setiap gelasnya.

\subsection{Kesimpulan Metode}

Kesimpulan dari metode regresi linier berganda yaitu:

1. Menghasilkan rumus regresi linier berganda dengan menggunakan data yang telah diuji.

$$
Y=687,96-0,78 X_{1}+2,84 X_{2}
$$

\section{Gambar VI.1: Rumus Regresi Linier Berganda}

2. Variabel X1 berpengaruh negatif terhadap variabel $\mathrm{Y}$.

3. Variabel X2 berpengaruh positif terhadap variabel $\mathrm{Y}$.

4. Variabel independen X1 dan X2, keduanya berpengaruh terhadap variabel dependen $\mathrm{Y}$.

5. Konstribusi dari variabel independen terhadap variabel dependen sebesar 97,2 persen.

\subsection{Kesimpulan Pengujian}

Kesimpulan dari alat yang telah dibuat yaitu:

1. Pompa peristaltik dapat bekerja dengan memompa air perasan jeruk sebanyak $70 \mathrm{ml}$ dalam waktu 60 detik. 
2. Pompa air dapat bekerja memompa air mineral sebanyak $300 \mathrm{ml}$ dalam waktu 10 detik.

3. Hasil test TDS Meter pada campuran minuman yang telah dibuat menyatakan kandungan elektrolit yang terkandung sebesar 654 PPM.

\section{DISKUSI}

Alat ini masih jauh dari kata sempurna. Masih terdapat beberapa bagian yang harus diperbaiki lebih dalam. Alat ini juga masih tergolong susah untuk digunakan, dikarenakan untuk mengganti jumlah takaran air yang keluar harus merubah script yang ada pada Arduinonya. Belum ada sebuah kontroller untuk merubah-rubah jumlah takaran air yang keluar. Tangki air yang digunakan hanya dapat menampung kurang lebih $700 \mathrm{ml}$ air. $700 \mathrm{ml}$ hanya cukup untuk mengisi maksimal 2 buah gelas minuman. Maka dari itu perlunya improvisasi pada bagian tangki air. Power untuk pompa peristaltik harus dinaikkan voltasenya. Pada penelitian ini menggunakan baterai $9 \mathrm{~V}$ yang masih kurang untuk menopang pompa apabila pompa bekerja optimal pada tegangan $12 \mathrm{~V}$.

\section{DAFTAR PUSTAKA}

[1] L. M. Wilson, "Keseimbangan cairan dan elektrolit serta penilaiannya," dalam: Patofisiologi Konsep Klinis Proses-proses Penyakit, Edisi ke-4, Penerbit Buku Kedokteran EGC, Jakarta, pp. 283-301, 1995.

[2] R. Yaswir and I. Ferawati, "Fisiologi dan gangguan keseimbangan natrium, kalium dan klorida serta pemeriksaan laboratorium," Jurnal Kesehatan Andalas, vol. 1, no. 2, 2012.

[3] A. Tamsuri, "Klien gangguan keseimbangan cairan dan elektrolit." EGC, 2009.

[4] P. A. Buwana, B. Widjasena, and S. Suroto, "Pengaruh pemberian air kelapa muda (cocos nucifera) terhadap kelelahan kerja pada nelayan di tambak mulyo semarang," Jurnal Kesehatan Masyarakat (e-Journal), vol. 4, no. 1, pp. 350-358, 2016.

[5] dr. Kevin Adrian, "Mengenal berbagai elektrolit dalam tubuh," 2017.

[6] J. Arifin, L. N. Zulita et al., "Perancangan murottal otomatis menggunakan mikrokontroller arduino mega 2560," Jurnal Media Infotama, vol. 12, no. 1, 2016.

[7] I. Oktariawan et al., "Pembuatan sistem otomasi dispenser menggunakan mikrokontroler arduino mega 2560," Jurnal Ilmiah Teknik Mesin, vol. 1, no. 2, 2013.

[8] L. Kamelia, S. A. Noorhassan, M. Sanjaya, and W. E. Mulyana, "Doorautomation system using bluetooth-based android for mobile phone," ARPN Journal of Engineering and Applied Sciences, vol. 9, no. 10, pp. 1759-1762, 2014.

[9] S. Nath, P. Banerjee, R. N. Biswas, S. K. Mitra, and M. K. Naskar, "Arduino based door unlocking system with real time control," in 2016 2nd International Conference on Contemporary Computing and Informatics (IC3I). IEEE, 2016, pp. 358-362.

[10] S. Gunputh, A. P. Murdan, and V. Oree, "Design and implementation of a low-cost arduinobased smart home system," in 2017 IEEE 9th International

Conference on Communication Software and Networks (ICCSN). IEEE, 2017, pp. 14911495.

[11] R. McLeod, "Sistem informasi manajemen jilid 1," Edisi Ketujuh. Alih Bahasa: Hendra Teguh. Jakarta: PT Prehallindo, 2001.

[12] S. Susanto and D. Suryadi, "Pengantar data mining: mengagali pengetahuan dari bongkahan data," 2010.

[13] R. Rosmiati, D. T. S. Junias, and M. Munawar, "Sikap, motivasi, dan minat berwirausaha mahasiswa," Jurnal Manajemen dan Kewirausahaan, vol. 17, no. 1, pp. 21-30, 2015.

[14] H. Santoso, Panduan praktis Arduino untuk pemula. ELANGSAKTI. com, 2015, vol. 1.

[15] M. Riza et al., "Rancang bangun pompa peristaltik dengan mekanisme penggerak manual," 2018.

[16] L. E. Maryanto, B. Basyirun, and S. Anis, "Pengaruh diameter roller terhadap debit pompa peristaltik," Sainteknol: Jurnal Sains

Muhammad Adam N.H, Mohamad Nurkamal Fauzan, Roni Habibi, Noviana Riza 
dan Teknologi, vol. 16, no. 1, pp. 65-72, 2018.

[17] K. Itahara, "Diaphragm pump," May 17 2016, uS Patent 9,341,176.

[18] M. K. RI, "Keputusan menteri kesehatan ri nomor 907/menkes/sk/vii/2002 tentang syarat-syarat pengawasan kualitas air minum-[peraturan]," 2002.

[19] K. Peffers, T. Tuunanen, M. A. Rothenberger, and S. Chatterjee, "A design science research methodology for information systems research," Journal of management information systems, vol. 24, no. 3, pp. 4577, 2007. 